\title{
Mixed Lineage Kinase Domain-Like Protein
}

National Cancer Institute

\section{Source}

National Cancer Institute. Mixed Lineage Kinase Domain-Like Protein. NCI Thesaurus.

Code C134711.

Mixed lineage kinase domain-like protein ( $471 \mathrm{aa}, \sim 54 \mathrm{kDa}$ ) is encoded by the human MLKL gene. This protein is involved in tumor necrosis factor-dependent necroptosis. 